U.S. Department of the Interior

U.S. Geological Survey

\title{
Remote Rainfall Sensing for Landslide Hazard Analysis
}

By Gerald F. Wieczorek, Harry C. McWreath, and Clay Davenport

U.S. GEOLOGICAL SURVEY OPEN-FILE REPORT 01-339 
U.S. Geological Survey Open-File Report 01-339

\section{REMOTE RAINFALL SENSING FOR LANDSLIDE HAZARD ANALYSIS}

Gerald F. Wieczorek ${ }^{1}$, Harry C. McWreath ${ }^{1}$, and Clay Davenport ${ }^{2}$

(1) U.S. Geological Survey, National Center, Reston, VA 20192, USA

(2) NOAA/NESDIS/ORA, Camp Springs, MD 20746, USA

\section{Abstract}

Methods of assessing landslide hazards and providing warnings are becoming more advanced as remote sensing of rainfall provides more detailed temporal and spatial data on rainfall distribution. Two recent landslide disasters are examined noting the potential for using remotely sensed rainfall data for landslide hazard analysis. For the June 27, 1995, storm in Madison County, Virginia, USA, National Weather Service WSR-88D Doppler radar provided rainfall estimates based on a relation between cloud reflectivity and moisture content on a 1-km resolution every 6 minutes. Ground-based measurements of rainfall intensity and precipitation total, in addition to landslide timing and distribution, were compared with the radar-derived rainfall data. For the December 14-16, 1999, storm in Vargas State, Venezuela, infrared sensing from the GOES-8 satellite of cloud top temperatures provided the basis for NOAA/NESDIS rainfall estimates on a $16-\mathrm{km}^{2}$ resolution every 30 minutes. These rainfall estimates were also compared with ground-based measurements of rainfall and landslide distribution. In both examples, the remotely sensed data either overestimated or underestimated ground-based values by up to a factor of 2 . The factors that influenced the accuracy of rainfall data include spatial registration and map projection, as well as prevailing wind direction, cloud orientation, and topography.

\section{Introduction}

Recent developments in remote sensing of weather information have provided the capability for more timely and spatially accurate assessments and warnings of weather-related hazards. Remote sensing of rainfall using Doppler radar and infrared satellite sensing can provide information on rainfall with a spatial and temporal resolution that is potentially useful for near real-time landslide hazard assessment and warning. Thresholds of rainfall intensity and duration for the triggering of landslides have been developed for many regions worldwide using ground-based rainfall measurements and documentation of landslides (Larsen and Simon, 1993; Crosta, 1998; and Wieczorek et al., 2000). Rainfall thresholds have been applied for regional real-time landslide warning (Keefer et al., 1987 and Hansen et al., 1995); however, techniques for analyzing the temporal variation in slope stability on a local scale during the course of a storm with interval rainfall input are now being developed (Morrissey et al., 2001).

Storms that have caused flash flooding in the central or western United States, such as the Big Thompson, Rapid City, and Fort Collins storms, have been associated with tropical meteorological characteristics of warm weather systems that produce exceptionally intense rainfall (Smith et al, 1996). These warm storm complexes can be very localized and remain stationary for 
many hours, resulting in exceptionally high cumulative rainfall.

In this paper we examine the cases of two landslide disasters where different methods of remote sensing provided rainfall estimates for comparison with ground-based measurements. Problems with and the limitations of using remote-sensed rainfall data for landslide hazard assessment and warning are discussed.

June 27, 1995, Madison County, Virginia, Storm
Heavy rainfall during the June 27, 1995, storm in Madison County along the Blue Ridge mountains of central Virginia, USA, triggered flooding and abundant ( 1000) shallow landslides, commonly referred to as debris flows, within a relatively small area of about $130 \mathrm{~km}^{2}$ (Fig. 1). The storm dropped up to $775 \mathrm{~mm}$ of rainfall during a period of about 14 hours (Wieczorek et al., 2000). Based upon eyewitness reports, landslides occurred when rainfall intensity ranged from 25 to $100 \mathrm{~mm} / \mathrm{h}$ (Fig. 2). The observed timing of landslide events showed a stronger correlation with rainfall intensity than with storm total, consistent with the concept of rainfall intensity-duration thresholds for the triggering of shallow landslides.

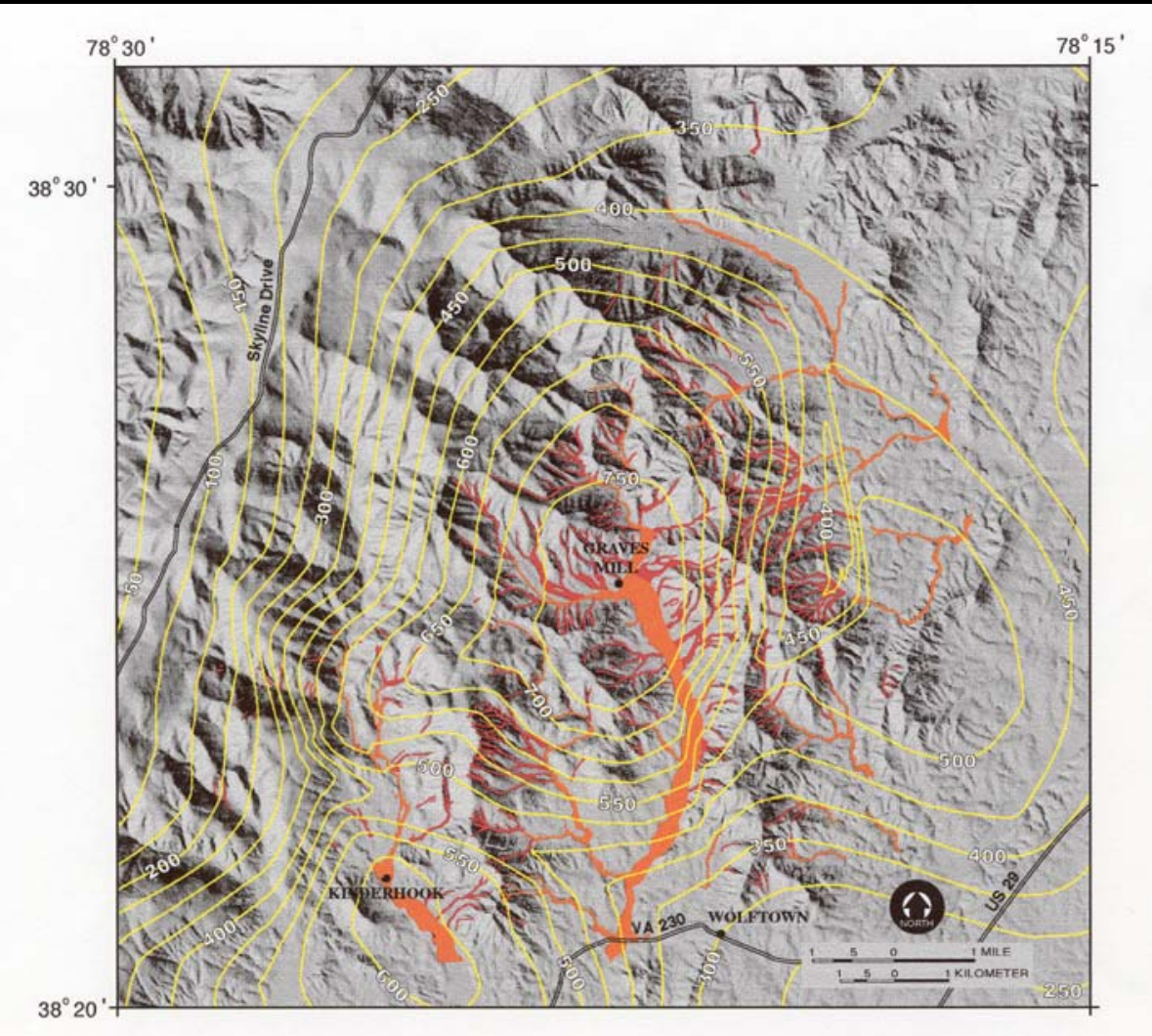

Figure 1. Shaded relief map of the Madison County region with rainfall contours (mm) from June 27, 1995, storm, areas of debris flow (red) and areas of flooding (orange). Densest concentration of landsliding near Graves Mill with the $750 \mathrm{~mm}$ rainfall contour. Crest of Blue Ridge along Skyline Drive (left side of figure) (Wieczorek et al., 2000). 


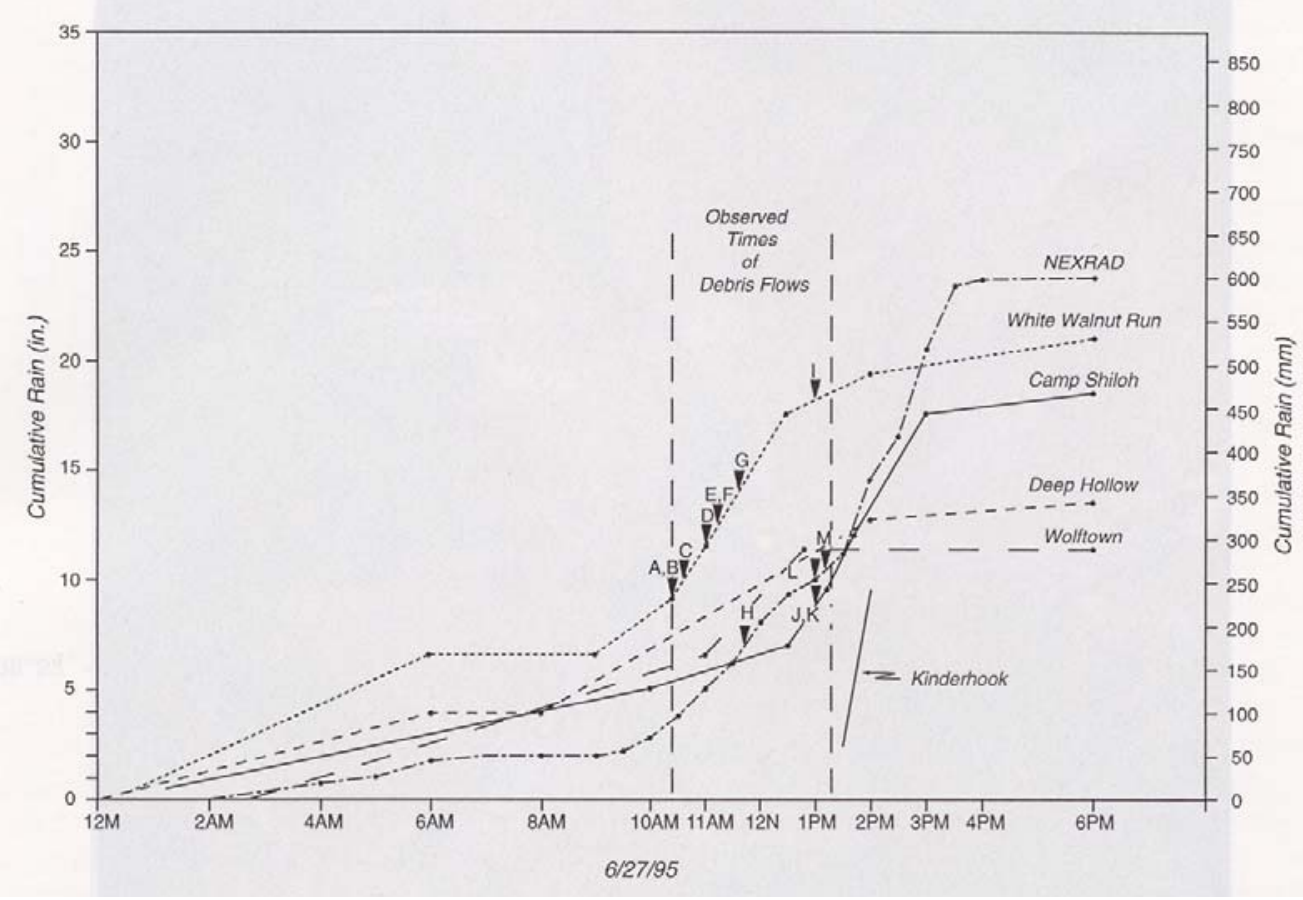

Figure. 2. Cumulative rainfall and observed times of debris flows shown as letters (A-M) with arrows on cumulative rainfall plot for station located closest to each observed debris flow. NEXRAD data from Smith et al. (1996) for cell with maximum cumulative rainfall show low value in comparison with ground-based values for periods of low rainfall rate early in the storm and a very similar rate of rainfall intensity (steepness of cumulative curve) during the higher rainfall rate after 10 am (Wieczorek et al., 2000).

The U.S. National Weather Service (NWS) WSR-88D (Weather Surveillance Radar1988 Doppler, also known as NEXRAD) reflectivity observations provide rainfall estimates based on a relation between cloud reflectivity and moisture content at distances up to about $225 \mathrm{~km}$. These estimates are based on the return of energy back toward the radar after impact with raindrops. The reflectivity, measured in $\mathrm{dBZ}$ (decibels of $\mathrm{Z}$ ), is related to rainfall intensity, $\mathrm{R}$, by the general formula $\mathrm{R}=\mathrm{a} \mathrm{Z}^{\mathrm{b}}$, where $\mathrm{a}$ and $\mathrm{b}$ are constants. The radar continuously scans the atmosphere by completing volume coverage patterns consisting of the radar making several $360^{\circ}$ scans of the atmosphere, sampling a set of increasing elevation angles, ranging from 0.5 to 19.5 degrees. A summary of moisture at different levels in the atmosphere is produced on a $1-\mathrm{km}^{2}$ resolution every 6 minutes. A survey of measured rainfall provided information for calibrating the NEXRAD rainfall data; Smith et al. (1996) found that these radar based rainfall estimates in the Madison storm underestimated ground-based measurements by a mean bias of 2.5 .

Several factors can account for differences between radar-based estimates of rainfall and ground-based measurements. The parameters $a$ and $b$ used in the equation for estimating rainfall rate from cloud reflectivity depend upon the size of raindrops. The initial values of these parameters derived for the relation between reflectivity and rainfall rate were based on raindrop size distribution in Florida, which may not apply equally well elsewhere (Smith et al., 1996). Given two storm cells with equivalent rainfall rate potential, a 
mixture of large hydrometeors (water and hail) can be seen as a more intense storm cell than one with a higher concentration of smaller raindrops. Tropical storms typically with dense concentrations of smaller raindrops are thus commonly underestimated in comparison to convective storms with large drops and hail. Hail is a good reflector of energy and will return very high "false" rainfall intensity values. Since in convective storms hail can cause the radar based rainfall estimates to be higher than what is actually occurring, steps are taken to prevent these high reflectance values from being converted to a high rainfall rate. A rainfall rate cap is applied to prevent anomalous rainfall rates associated with hail. Thus higher reflectivity values, corresponding to higher intensities associated with tropical storms, are sometimes misinterpreted as hail and, when the rainfall rate cap is applied, results in an underestimation of rainfall.
Low-centroid convection can often result in underestimated intensity because of belowbeam effects as well as intervening topography. The further the storm from the radar, the greater the possibility that the lowest parts of the storm may be underdetected. The Madison storm had a low centroid of less than $4 \mathrm{~km}$ elevation with near-saturated atmosphere column up to only $6 \mathrm{~km}$ (Fig. 3). No prominent topography between the NWS radar at Sterling and Madison County obstructed the signal. However, late in the evening of June 26, 1995, intense rainfall from a different strong storm cell caused numerous debris flows along the North Fork, Moormons River, about $40 \mathrm{~km}$ southeast of the Madison County storm (Morgan and Wieczorek, 1996). This very localized storm cell could not be detected on radar because of an intervening ridge between the Moormons River and Sterling.

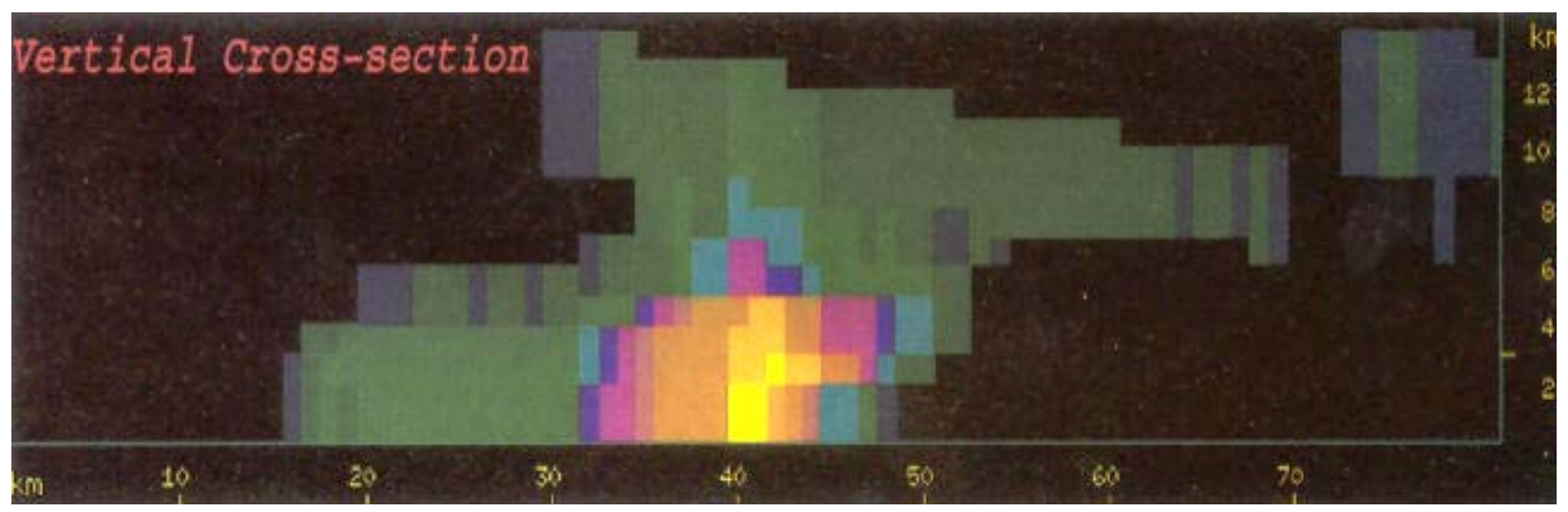

Figure. 3. Vertical (west-left to east-right) cross section of reflectivity from radar of the July 27, 1995, Madison storm at 13:47 UTC (Smith et al., 1996). Both horizontal and vertical scale are in kilometers. Vertical scale shows storm inclined to the east with height (to right) with most intense part of storm within lowest $4 \mathrm{~km}$. Yellow cells indicate reflectance of 51-54 dBZ, corresponding to a rainfall rate of about $60-100 \mathrm{~mm} / \mathrm{h}$ without correction factor. 
Wind direction, cloud structure or orientation and topography can also complicate interpretation of radar-based rainfall estimates. During the Madison storm, the track of storm propagation was from northeast to southwest, roughly parallel to the direction of the crest of the Blue Ridge, and was influenced by topography of lower secondary ridges that extend southward from the Blue Ridge. Within the storm column strong boundary layer winds were directed upslope towards the Blue Ridge near ground level with weak upper level winds. The cloud structure sloped to the east, away from the crest of the Blue Ridge, with height. Maximum rainfall amounts were not observed at the crest of the Blue Ridge ( 1000 m), rather at intermediate elevations near Graves Mill $(\sim 300 \mathrm{~m})$ (Fig. 1). Since rainfall rate based on cloud reflectivity vertically projects the value of rainfall to the ground surface, rain falling at an angle because of wind will affect those estimates. Radar-based rainfall estimates of the Madison storm were probably influenced by wind direction and cloud structure, although no methods exist for determining the magnitude of this effect.

\section{December 14-16, 1999, Vargas State, Venezuela Storm}

A storm on December 14-16, 1999, caused catastrophic flooding and landslides along a 40-km coastal strip from Maiquetia to Naiguata north of Caracas in the northern coastal state of Vargas, Venezuela (Fig. 4), resulting in extensive damage to communities and infrastructure with as many as 19,000 casualties (Wieczorek et al, 2001). The topography of this region of coastal Venezuela is extremely steep and rugged. The crest of the Sierra de Avila reaches 2,700 m within about 6-10 km of the coast. 


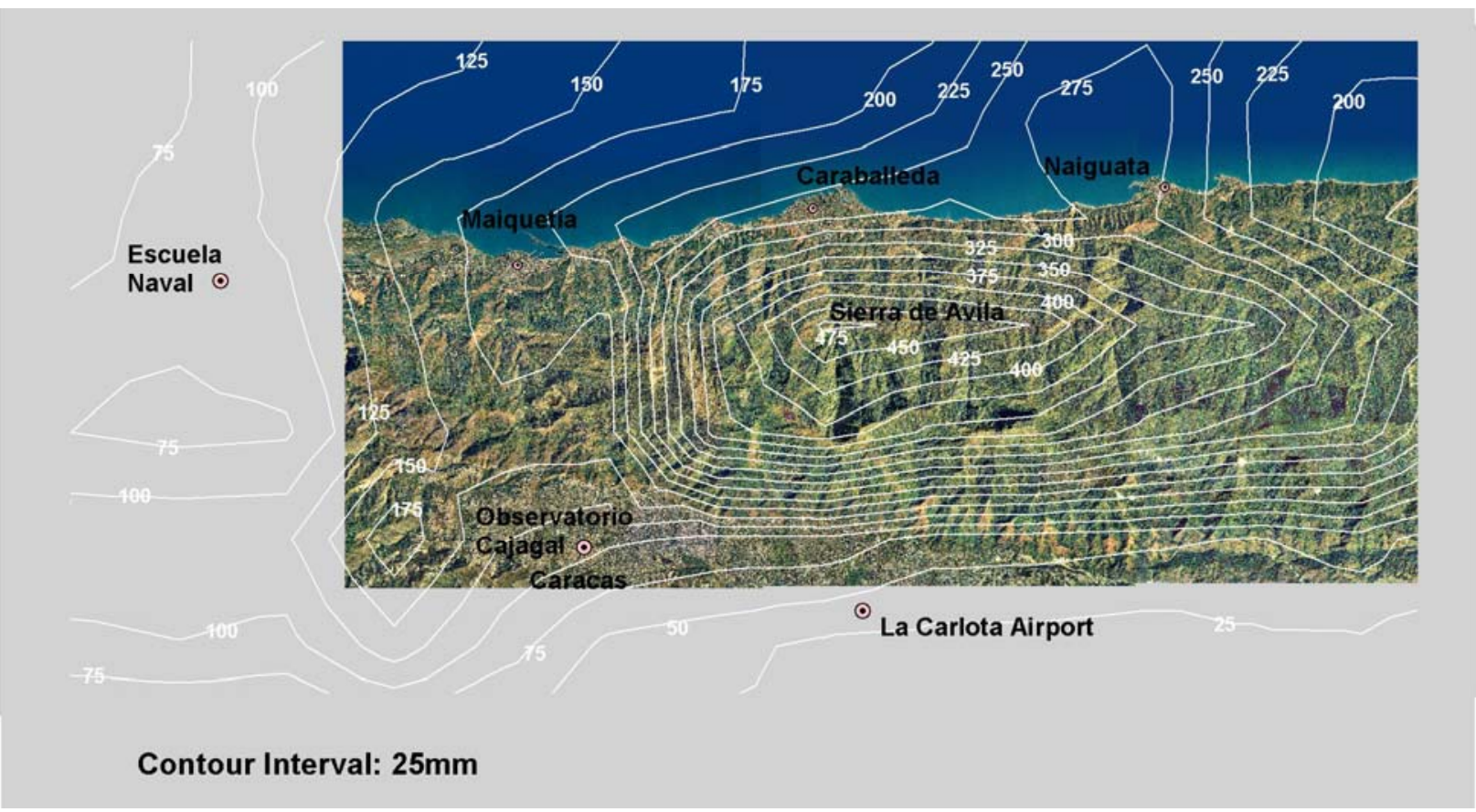

Figure 4. Map of estimated rainfall on December 14-16,1999, storm in coastal Venezuela from GOES-8 satellite data with isohyets (white lines) in 25-mm interval values. The area upslope of Caraballeda towards the crest of the Sierra de Avila with the highest rainfall totals was the center of the most intense landslide and flooding activity in the storm. Locations of hourly rainfall measurements at Escuela Naval along coast and at Observatorio Cajugal and La Carlota airport in Caracas are shown. The storm total from the daily rainfall measured at Maiquetia greatly exceeded the GOES-8 rainfall estimate.

The timing and intensity of rainfall of the storm of December 14-16, 1999, was unusual because the rainy season in coastal Venezuela normally lasts from May through October. Beginning in early December of 1999, the interaction of a cold front with moist southwesterly flow from the Pacific Ocean towards the Caribbean Sea resulted in an unusually wet period over coastal northern Venezuela. The total 3-day rainfall along the Caribbean coast at the International Airport at Maiquetia (43 m above mean sea level) for a 52-hour span on December 14-16 totaled $911 \mathrm{~mm}$. Hourly rainfall from 6 to $7 \mathrm{am}$ on the morning of December 16 measured $72 \mathrm{~mm}$; daily totals of 380.7 and $410.4 \mathrm{~mm}$ were recorded at Maiquetia for both December 15 and 16. These amounts of rainfall were highly exceptional for this region.
Limited ground-based rainfall measurements of this storm were available, particularly within the heavily damaged State of Vargas. A spatial and temporal representation of distribution of rainfall was developed from the NOAA/NESDIS rainfall estimates of the data from the GOES-8 infrared satellite sensor (Fig. 4). The GOES-8 satellite data of cloud top temperatures provided the basis for rainfall estimates on a $16-\mathrm{km}^{2}(4 \mathrm{x} 4 \mathrm{~km}$ grid) resolution every 30 minutes. The GOES-8 data spans 52 hours, from 19:45 on Dec. 15 to 23:45 on Dec. 17, UTC. These rainfall estimates have been computed using a relation between rainfall rate and cloud top temperature determined from infrared sensors on the GOES-8 satellite. This procedure was developed for convective storms rather than tropical storms, as in the case of the December 1999 Venezuela. 
Original calibration of the rainfall rate for the GOES-8 satellite was performed on the relatively flat topography in the central Great Plains and in areas adjacent to the Gulf of Mexico using WSR-88D doppler radar and ground-based measurements (Vicente et al., 1998; Cecilia Girz, NOAA, written commun., 10/5/2000).

Ground-based rainfall measurements from previous storms in this region indicate that the higher elevations towards the crest of the Sierra de Avila receive about twice as much rainfall as the regions along the coast (Salcedo, 2000). A map of rainfall contoured from the GOES-8 data shows that the heaviest rainfall occurred within $8 \mathrm{~km}$ of the coast and the higher elevations of the Sierra de Avila roughly centered over the mid to upper part of the drainages upstream of Caraballeda. Rainfall decreased towards Caracas on the southern side of the crest of the Sierra de Avila and to the east of Naiguata and to the west towards Maiquetia along the coast. These areas of heavy rainfall roughly corresponded to the areas that suffered the most abundant landslides and most severe flooding and debris-flow damage.

Comparison of the limited ground-based rainfall measurements with the rainfall estimates from GOES-8 satellite data showed that these two sets of values were inconsistent with each other (Figure 5). The factors that influenced the accuracy of remotely sensed rainfall data include spatial registration and map projection, as well as prevailing wind direction, cloud structure, size, orientation, and topography. In this storm, ground-based cumulative rainfall measurements along the coast at Escuela Naval greatly exceeded the GOES-8 values (Fig. 5 a, b); however, southward over the crest of the Avila within Caracas, the GOES-8 rainfall values slightly exceeded the ground-based measurements at Observatorio Cajigal (Fig. 5 c,d), but severely underestimated the measurements at La Carlota Airport (Fig. 5 e, f).

With a grid cell size of $4 \mathrm{~km}$, comparison of ground-based measurements with GOES-8 data is sensitive to spatial registration of the remote imagery. Our first analysis of the areal distribution of most severe landslide and flooding was not consistent with the region of greatest rainfall from the GOES-8 data. Subsequently, detecting an error in the formula for registration of the cell centroids in the Venezuela data resulted in a shift of about $6 \mathrm{~km}$; this correction adjusted the storm center isohyets over the area with greatest landslide density. 

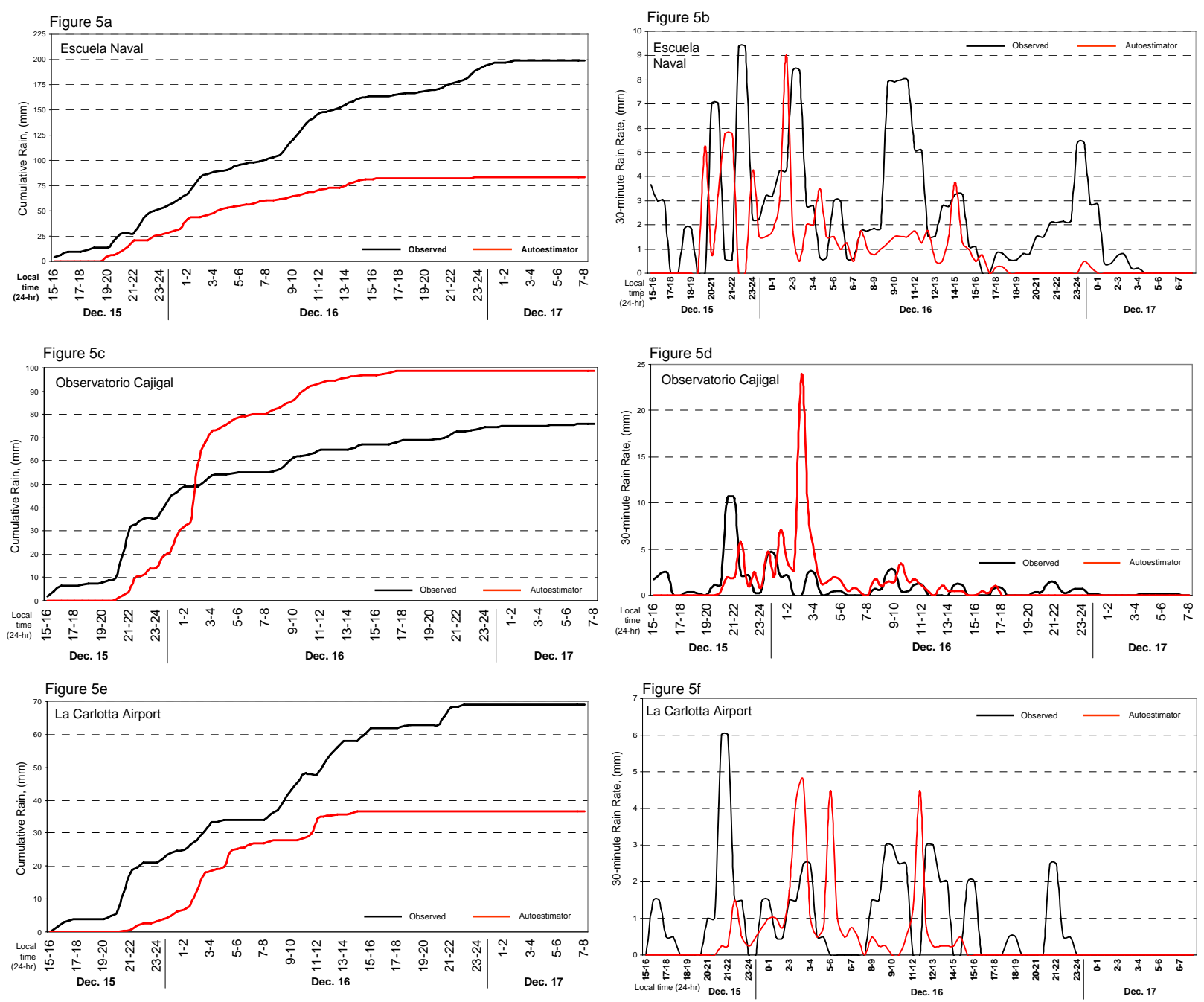

Figure 5 (A-F). Comparison of ground-based rainfall measurements with GOES-8 autoestimator values taken at 30minute intervals. Cumulative and 30-minute rainfall rates at Escuela Naval (A,B), Observatorio Cajugal (C, D), and La Carlota Airport (E, F). Note discrepancy between cumulative rainfall totals and timing of intense periods of rainfall. At various locations flooding was reported at $8 \mathrm{pm}$, Dec. 15, followed by debris flows at 8:30 pm; flooding again occurred from 1-2 am followed by debris flows from 2-3 am Dec. 16; additional debris flows were noted from 5-9 am Dec. 16 local time.

\section{Discussion}

In Venezuela, as well as in other areas, the orographic effects of topography are known to affect rainfall distribution. As clouds rise to higher elevations, the temperature drops, and the capability for the cloud to retain moisture lessens resulting in more rainfall. Orographic effects increase rainfall with increased topography for windward and decrease for leeward cases. The highest elevations do not necessarily receive the maximum rainfall; typically the maximum rainfall occurs from about 1/3 to about midway up the slope. Orographic effects are not typically accounted for in calculating rainfall from GOES-8 data. NWS research is underway to account for orographic effects with GOES-8 rainfall data in coastal mountainous regions of California. 
The exceptionally steep coastal section of Venezuela probably received amounts of rainfall several times greater than indicated by the GOES-8 data, based on the underestimation of values at coastal stations and consistent with orographic effects measured in previous storms in this region (Salcedo, 2000). Cirrus clouds that shield storm clouds can lead to errors in rainfall estimation (Cecilia Girz, NOAA,written commun., 10/5/2000). For exceptionally high clouds (e.g. $20 \mathrm{~km}$ ), the sensing of cloud top temperatures might result in underestimating the temperature lower in the cloud structure because at lower elevations the warmer parts of clouds are able to hold more moisture. Another important factor in estimating rainfall is that the measurement of cloud top temperatures with the GOES-8 sensor does not account for cloud orientation in the storm. Strong winds were associated with the Venezuela storm, but measurements of wind velocity and direction were not available for analysis.

\section{Conclusions}

WSR-88D Doppler radar and GOES-8 satellite sensor can provide near real time rainfall data potentially applicable for landslide hazard analysis. The radar-based estimates are better than the satellite techniques in several respects. Using the energy return of the radar beam on raindrops provides a more direct measurement of rainfall than infrared sensing of cloud top temperature by satellite. The resolution of Doppler radar $\left(1 \mathrm{~km}^{2}\right)$ is considerably better than the GOES-8 satellite $\left(16 \mathrm{~km}^{2}\right)$ for assessing landslide hazards. The time interval with the Doppler radar (6 minutes) is considerably better compared with the GOES-8 (30 minutes over Caribbean and South America; 15 minutes over the United States) for issuing landslide warnings. However, the potential blocking of radar by topography is a serious limitation, particularly in areas of steep topography that can be particularly prone to landslides.

These two cited examples of landslide disasters indicate that neither radar nor satellite estimates of rainfall are yet sufficiently developed for quantitative measurements of rainfall for near real-time landslide hazard assessment. Although periods of intense rainfall appear to be better identified than storm totals using remote sensing, neither NEXRAD nor GOES-8 data would be sufficiently accurate for the issuance of landslide warnings. In both cases of Madison, Virginia, and Vargas, Venezuela, remotely sensed data either overestimated or underestimated groundbased values by up to a factor of 2 . Although unofficial measurements made in bucket surveys may likewise be subject to inaccuracies, the relatively small areas affected by similar extremely severe storms make it unlikely that a sufficient number of official gages will be available to adequately characterize the rainfall. Unfortunately, increasing reliance on remote sensing rather than ground-based measurements is making it more difficult to verify estimated rainfall based on remote sensing in such storms.

Even more sophisticated rainfall gage networks are subject to disruption such as occurred in the West Virginia storms of July 8,2001 . The rainfall in these storms that triggered flooding and landslides in southern West Virginia was measured using the IFLOWS system of automatic reporting gages operated throughout the Appalachian states in the eastern United States, but the main computer failed to archive the data.

Additional research on remote sensing of rainfall could improve the utilization of rainfall data for real-time landslide assessment. Although warm storms with extremely intense rainfall, such as the 1997 
Fort Collins, 1976 Big Thompson, 1972 Rapid City , and 1995 Madison County events, may be exceptional, these storms are important to study because of their propensity to cause flooding and landslides. Overlapping radar coverage in some areas may make it possible for more complete comparison of rainfall estimates; however, ground-based rainfall measurements are still needed to verify remote-sensed estimates.
Post-event comparisons of ground-based rainfall measurements with remote sensed data for major storms are needed, particularly in areas with major topographic relief, to improve understanding of storm processes and to improve rainfall-estimating techniques based on remote sensing. Improved assessment of localized tropical storms is needed for providing accurate estimates of rainfall totals.

\section{References}

Crosta, Giovanni, 1998, Regionalization of rainfall thresholds: an aid to landslide hazard evaluation, Environmental Geology, v. 35, n. 2-3, pp. 131-145.

Hansen, A., Franks, C.A.M., Kirk, P.A., Brimicombe, A.J., and Tung, Fung, 1995, Application of GIS to hazard assessment, with particular reference to landslides in Hong Kong; in Carrara, Alberto, and Guzzetti, Fausto, eds., Geographical Information Systems in Assessing Natural Hazards, Kluwer Academic Publishers, pp. 273-298.

Keefer, D.K., Wilson, R.C., Mark, R.K., Brabb, E.E., Brown, W.M. III, Ellen, S.D., Harp, E.L., Wieczorek, G.F., Alger, C.S., and Zatkin, R.S., 1987, Real-time landslide warning during heavy rainfall: Science, v. 238, p. 921-925.

Larsen, M.C., and Simon, Andrew, 1993, A rainfall-intensity-duration threshold for landslides in a humid-tropical environment, Puerto Rico: Geografiska Annaler, v. 75A, n. 1-2, pp. 1323.

Morgan, B.A. and Wieczorek, G.F., 1996, Inventory of debris flows and landslides resulting from the June 27, 1995, storm in the North Fork Moormans River, Shenandoah National Park, Virginia, U.S. Geological Survey Open-File Report 96-503, 10 p., 1 plate, 1:24,000.

Morrissey, M.M., Wieczorek, G.F., and Morgan, B.A., 2001, A comparative analysis of hazard models for predicting debris flows in Madison County, Virginia: U.S. Geological Survey Open-File Report 01-67, 17 p., 7 figs., 1 CD.

Salcedo, D.A., 2000, Los flujos torrenciales catastróficos de Diciembre de 1999, en el estado Vargas y en Caracas: Características y lecciones apprendidas. Memorias XVI Seminario Venezolano de Geotecnia, Caracas. p. 128-175.

Smith, J.A., Baeck, M.L., Steiner, Matthias, and Miller, A.J., 1996, Catastrophic rainfall from an upslope thunderstorm in the central Appalachians: The Rapidan storm of June 27, 1995: Water Resources Research., v. 32, n. 10, pp. 3099-3113. 
Vicente, G.A., Scofield, R.A., and Menzel, W.P, 1998, The operational GOES Infrared rainfall estimation technique, Bulletin of American Meteorological Society, v. 79, pp. 1883-1898.

Wieczorek, G.F., Morgan, B.A., and Campbell, R.H., 2000, Debris-flow hazards in the Blue Ridge of central Virginia: Environmental \& Engineering Geoscience, v. VI, n. 1, p. 3-23.

Wieczorek, G.F., Larsen, M.C., Eaton, L.S., Morgan, B.A. and Blair, J. L., 2001, Debris-flow and flooding hazards associated with the December 1999 storm in coastal Venezuela and strategies for mitigation: U.S. Geological Survey Open-File Report 01-144, 40 p., 3 tables, 2 appendices, 3 plates, 1 CD, (http://geology.cr.usgs.gov/pub/open-filereports/ofr-01-0144/). 